\title{
Scorpions from Mexico: From Species Diversity to Venom Complexity
}

\author{
Carlos E. Santibáñez-López ${ }^{1, *}$, Oscar F. Francke ${ }^{2}$, Carolina Ureta ${ }^{3}$ and Lourival D. Possani ${ }^{1}$
}

Received: 28 October 2015; Accepted: 9 December 2015; Published: 24 December 2015

Academic Editor: Ren Lai

1 Departamento de Medicina Molecular y Bioprocesos, Instituto de Biotecnología, Universidad Nacional Autónoma de México, Avenida Universidad 2001, Apartado Postal 510-3, Cuernavaca Morelos 62210, Mexico; possani@ibt.unam.mx

2 Colección Nacional de Arácnidos, Instituto de Biología, Universidad Nacional Autónoma de México, Circuito exterior s/n, Ciudad Universitaria, Copilco, Coyoacán A.P. 70-233, Distrito Federal 04510, Mexico; offb@ib.unam.mx

3 Laboratorio de Genética Molecular, Desarrollo y Evolución de Plantas, Departamento de Ecología Funcional, Instituto de Ecología, Universidad Autónoma de México, Apartado Postal 70-275, Ciudad Universitaria, Distrito Federal 04510, Mexico; carolina_ureta@hotmail.com

* Correspondence: cae@ibt.unam.mx; Tel.: +52-77-7312-1709

\begin{abstract}
Scorpions are among the oldest terrestrial arthropods, which are distributed worldwide, except for Antarctica and some Pacific islands. Scorpion envenomation represents a public health problem in several parts of the world. Mexico harbors the highest diversity of scorpions in the world, including some of the world's medically important scorpion species. The systematics and diversity of Mexican scorpion fauna has not been revised in the past decade; and due to recent and exhaustive collection efforts as part of different ongoing major revisionary systematic projects, our understanding of this diversity has changed compared with previous assessments. Given the presence of several medically important scorpion species, the study of their venom in the country is also important. In the present contribution, the diversity of scorpion species in Mexico is revised and updated based on several new systematic contributions; 281 different species are recorded. Commentaries on recent venomic, ecological and behavioral studies of Mexican scorpions are also provided. A list containing the most important peptides identified from 16 different species is included. A graphical representation of the different types of components found in these venoms is also revised. A map with hotspots showing the current knowledge on scorpion distribution and areas explored in Mexico is also provided.
\end{abstract}

Keywords: mexico; neotropical; nearctic; buthidae; diplocentridae; vaejovidae; venom; diversity hotspots

\section{Introduction}

The order Scorpiones is a distinctive group of arachnids including the oldest fossils in the class, dating back to almost 433-438 mya [1,2]. Scorpion groundplan has remained almost unchanged ever since they became fully terrestrial. Despite this conservative morphology, scorpions successfully colonize different ecosystems, from the deepest caves in Mexico (e.g., Alacran tartarus Francke, 1982 at $900 \mathrm{~m}$ below ground level [3]) to some of the highest peaks in the Andes Cordillera (Orobothriurus huascaran at $4910 \mathrm{~m}$ [4]), and some harsh environments such as dunes or deserts with high temperatures [5,6]. Scorpions are distributed worldwide except in Antarctica, the boreal areas and some oceanic islands [7]. The greatest diversity of scorpions occurs in subtropical areas and decreases towards the equator and the poles [6]. 
Although they are not as morphologically diverse as opilionids, spiders and mites, the order comprises nearly 2231 species in 208 genera and 20 families [8,9], including the species enlisted in this contribution.

Scorpion systematics is problematic and in continual change. Prendini and Wheeler [10] proved that a more detailed study on scorpion phylogenetics is necessary to achieve uniformity in the taxonomy and a stable classification. Therefore, several taxonomic revisions on different scorpions' genera are more common these days and the number of species has increased rapidly, along with changes in their classification. However, recent phylogenetic and phylogenomic approaches to reveal species evolutionary history are contrasting with the morphological phylogenetic indications [11].

The remarkable scorpion diversity of Mexico has been recognized for more than 30 years. Several authors [12-19] have summarized the diversity of scorpions in Mexico (for previous works before 1970 of Mexican scorpions refer to [16,19]).

Scorpion diversity in Mexico, with 281 species described (until October 2015), represents more than $12 \%$ of the worldwide diversity (Table 1). Although recent efforts have been made to collect scorpions across the entire country (i.e., Revisionary Systematics of the family Vaejovidae Thorell, 1876 project), there are several areas not yet accessed or that remain poorly sampled (e.g., Sinaloa, Sonora, Tamaulipas, and Coahuila). Even though most of the species are recorded in several localities and from several specimens, many others are recorded only from type localities, and from single specimens, which could affect the endemism levels reported [16,19]. When the sampling is not exhaustive, the information available might be deficient. In addition, for the same reason, the species considered endemic of one given place can eventually be found in other areas.

Table 1. Comparative list between Mexican scorpion fauna and world's diversity. The list includes known introduced species, but not subspecies. Percentages are of the total genera and species worldwide represented in the country.

\begin{tabular}{ccccccc}
\hline \multirow{2}{*}{ Families } & \multicolumn{2}{c}{ Worldwide } & \multicolumn{4}{c}{ Mexico } \\
\cline { 2 - 7 } & Genera & Species & Genera & Species & \% Genera & \% Species \\
\hline Akravidae & 1 & 1 & 0 & 0 & 0 & 0 \\
Bothriuridae & 16 & 150 & 0 & 0 & 0 & 0 \\
Buthidae & 92 & 1054 & 2 & 44 & 2 & 4 \\
Caraboctonidae & 5 & 31 & 3 & 9 & 60 & 29 \\
Chactidae & 12 & 178 & 1 & 1 & 8 & 1 \\
Chaerilidae & 1 & 40 & 0 & 0 & 0 & 0 \\
Diplocentridae & 10 & 121 & 3 & 58 & 30 & 48 \\
Euscorpiidae & 4 & 51 & 3 & 8 & 75 & 16 \\
Hemiscorpiidae & 1 & 15 & 0 & 0 & 0 & 0 \\
Heteroscorpionidae & 1 & 6 & 0 & 0 & 0 & 0 \\
Hormuridae & 11 & 81 & 0 & 0 & 0 & 0 \\
Iuridae & 4 & 39 & 0 & 0 & 0 & 0 \\
Pseudochactidae & 3 & 6 & 0 & 0 & 0 & 0 \\
Scorpionidae & 9 & 152 & 0 & 0 & 0 & 0 \\
Scorpiopidae & 6 & 67 & 0 & 0 & 0 & 0 \\
Superstitioniidae & 1 & 1 & 1 & 1 & 100 & 100 \\
Troglotayosicidae & 2 & 5 & 0 & 0 & 0 & 0 \\
Typhlochactidae & 4 & 11 & 4 & 11 & 100 & 100 \\
Urodacidae & 2 & 22 & 0 & 0 & 0 & 0 \\
Vaejovidae & 23 & 201 & 21 & 149 & 91 & 74 \\
\hline Totals & 208 & 2231 & 38 & 281 & 18 & 13 \\
\hline
\end{tabular}

In the present contribution, the Mexican scorpion species diversity is revised. It is not the scope of this contribution to cover the entire history of scorpion taxonomy research in Mexico, but to briefly update it from the last contribution in 2005. To learn about the history of scorpion studies in Mexico before the year 2005, please refer to Lourenco and Sissom [16] and Sissom and Hendrixson [19]. 
Updated species lists and their distribution within Mexican political divisions are provided. Although several authors argue against the study of distributional and endemism patterns using geopolitical boundaries, we agree with other authors (i.e., [19]) that these studies are necessary to provide enough information for governmental decisions on biodiversity conservation. A review on the knowledge of general aspects of scorpions, such as ecology, behavior and venomic studies for Mexican scorpion species, is also included.

\section{Scorpion Taxonomy and Systematics}

As mentioned above, scorpion systematics and taxonomy have been changing in recent years. We agree with Prendini and Wheeler [10] on the need for a rigorous phylogenetic analysis using as much information as possible in order to propose a valid classification. Therefore, for this contribution, we follow Prendini's [8] familial and generic classifications, but with some modifications. These modifications are based on the observations recently discussed elsewhere (i.e., [20-22]).

We recognize, therefore, 2231 species in 208 genera and 20 families (see Table 1 and [8]).

\section{Mexican Scorpion Diversity}

We recognize eight families, 38 genera and 281 species distributed in Mexico (Figures 1-3; Table 1; Supplementary Materials). Vaejovidae Thorell, 1876 comprises $52 \%$ of the Mexican scorpion species diversity, Diplocentridae Karsch, 1880 and Buthidae Koch, 1837 represent $21 \%$ and $16 \%$ respectively, and lower diversity is found in families Typhlochactidae Mitchell, 1971, Caraboctonidae Kraepelin, 1905 and Euscorpiidae Laurie, 1896, representing 4\%, 3\% and 3\%, respectively; and the rest of the families the remaining 1\% (Chactidae Pocock, 1893 and Superstitioniidae Stahnke, 1940; see Figure 1).

Of the eight families in Mexico, only Typhlochactidae is strictly endemic to the country (see Section 2.7), although Superstitioniidae is 100\% represented in Mexico. Vaejovidae is distributed in Mexico and US; however, it is by far more diverse in Mexico than in US. Twenty-one genera are recorded in Mexico (eight endemic) while 13 are found in US (three endemic). Diplocentridae is also distributed in Mexico and US, but its distribution extends to northern South America and the Caribbean islands. Two genera are endemic to Mexico. Three of the four genera comprised in Euscorpiidae are found in Mexico, two genera are endemic. The only chactid representative in Mexico is endemic, and Superstitioniidae and Caraboctonidae are shared between Mexico and US, except for one caraboctonid genus endemic to central Mexico (see Section 2.2). Finally, one buthid genus is endemic to the Pacific coast of Mexico.
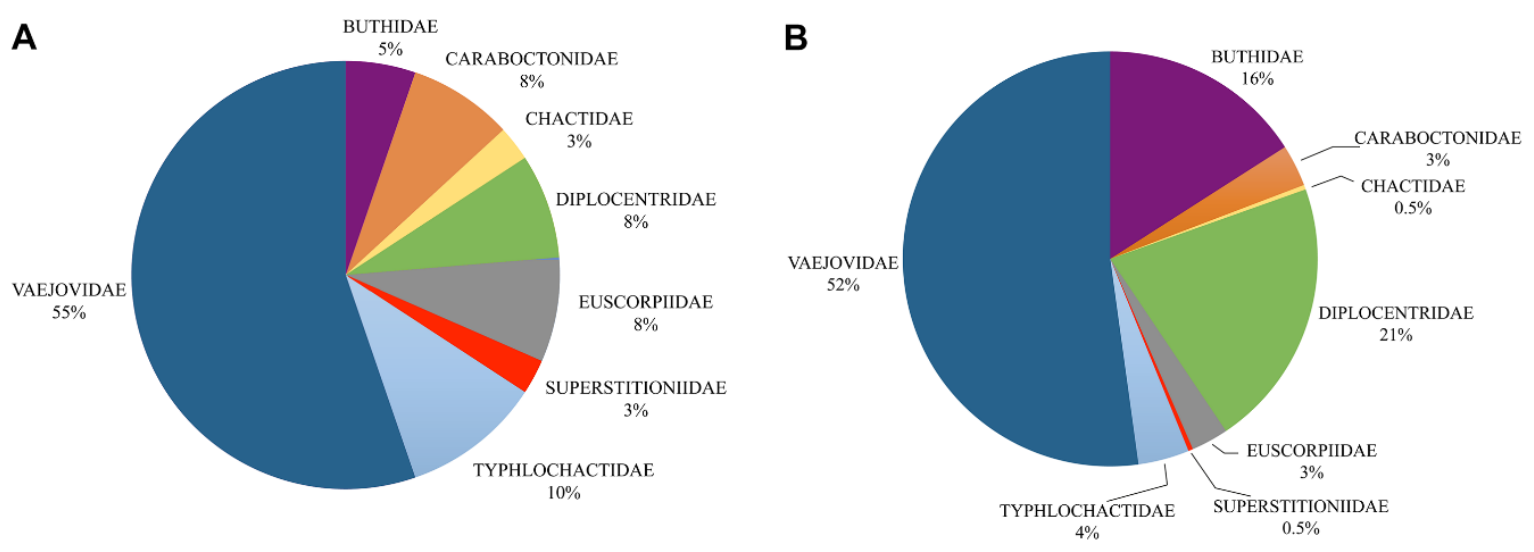

Figure 1. Proportion of scorpion diversity in Mexico. (A) Percentage of genera in the families of Mexican scorpions; (B) Percentage of species in the families of Mexican scorpions. 


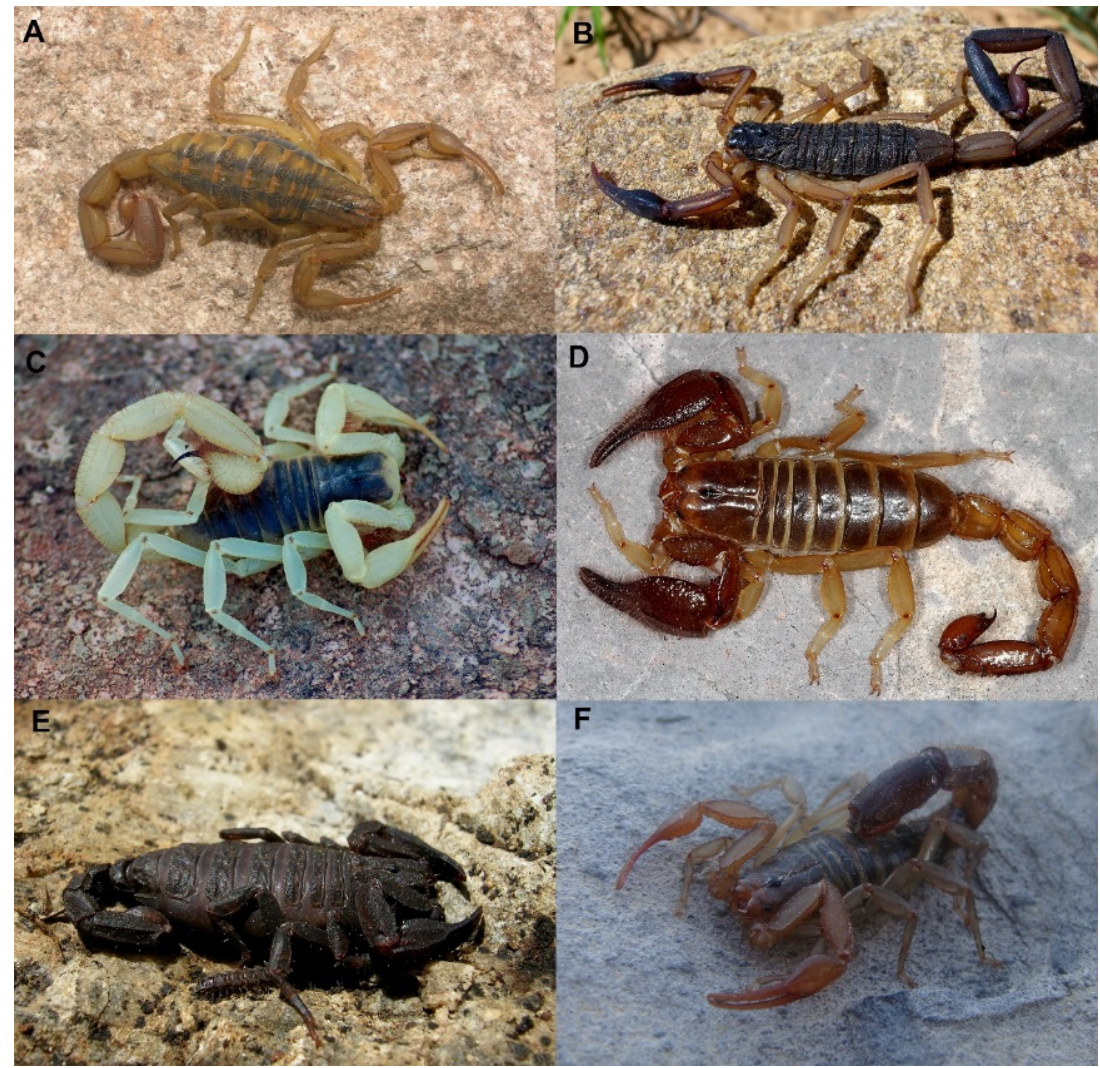

Figure 2. Representative scorpion species of families from Mexico: (A) Adult +Centruroides limpidus (Karsch, 1879) (Buthidae); (B) Adult +Centruroides nigrimanus (Pocock, 1898) (Buthidae); (C) Adult $\sigma^{7}$ Hadrurus obscurus Williams, 1970 (Caraboctonidae); (D) Adult ơ Diplocentrus colwelli Sissom, 1986 (Diplocentridae); (E) Adult + Megacormus segmentatus (Pocock, 1900) (Euscorpiidae); (F) Adult ơ Franckeus kochi (Sissom, 1991) (Vaejovidae).

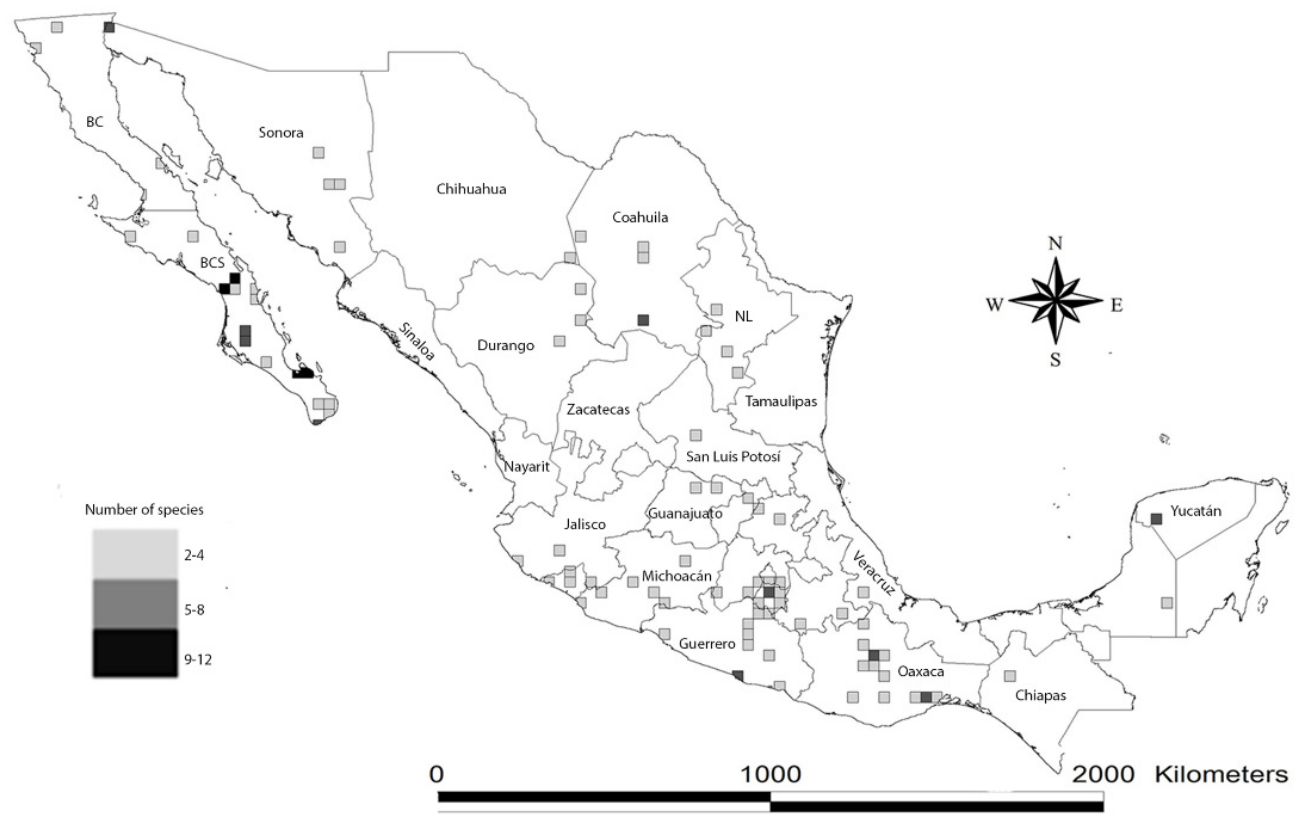

Figure 3. Hotspots of scorpion species richness in Mexico, expressed as the number of species per quarter-degree square mapped onto a Mexican geopolitical division map. 


\subsection{Family Buthidae C.L. Koch, 1837}

Two genera are represented by nearly 44 extant species, plus two fossil species of a third genus (Tityus) from Chiapas [23] (not considered in our counts). Genus Centruroides Marx, 1860 is by far the most diverse scorpion genus of this family in Mexico (Figure 2A,B). Currently, this genus comprises 42 species distributed acrosss almost the entire territory, but its highest diversity is found in Southern Mexico (in the states of Michoacán, Guerrero and Oaxaca). However, this estimation is still far from reality and it will be outdated soon. Despite the great interest in the study of the diversity of this genus in Mexico by several authors (i.e., $[17,24-26])$, the taxonomy of this genus has been long related to coloration patterns and morphometrics, making the diagnosis of some species difficult. Also, the vast majority of studies on Centruroides are mostly of its venom, given that less than a dozen Mexican species have highly toxic venoms to humans (see venomic studies section).

Recently, Francke et al. [27] described a new genus from the Pacific coast of Guerrero and Oaxaca (Southern Mexico). Chaneke Francke, Teruel \& Santibáñez-López, 2014 is a small orange-reddish brown buthid, with decreasing neobothriotaxy, and both species are morphologically similar to some species of Alayotityus Armas, 1973 from Cuba. This genus is poorly sampled, poorly represented in museum collections and its venom, ecology and behavior have not been studied at all.

\subsection{Family Caraboctonidae Krapelin, 1905}

Three genera are distributed in Mexico including the biggest scorpions in North America (reaching up to $150 \mathrm{~mm}$ ). Although some Centruroides and some diplocentrids reach this length, Hadrurus and Hoffmannihadrurus species have a more robust body. Hadrurus Thorell, 1876 (Figure 2C) is represented by six species, all of them distributed in Northern Mexico. Six species are recorded in Baja California Peninsula and one in Sonora. Hoffmannihadrurus Soleglad \& Fet, 2004 is regarded as distinct from Hadrurus Thorell, 1876 based on several characters. Two species are included in this genus: Hoffmannihadrurus aztecus (Pocock, 1900) distributed in Cuicatlán-Tehuacán valley in Oaxaca and Puebla; and Hoffmannihadrurus gertschi (Soleglad, 1976) distributed in southern Morelos and northern Guerrero. Finally, one species of Anuroctonus is distributed in Baja California (Anuroctonus pococki Soleglad and Fet, 2004).

\subsection{Family Chactidae Pocock, 1893}

Nullibrotheas allenii (Wood, 1863) is an endemic member of the Mexican fauna and the only representative of family Chactidae in the Nearctic region. It is distributed in the southern half of Baja California Sur [5]. It is easily recognized by the presence of six trichobothria in the ventral surface of the pedipalp patella. This species is light to pale yellow brownish and medium sized.

\subsection{Family Diplocentridae Karsch, 1880}

Scorpions of this family are easily recognized by the presence of a subaculear tubercle, also by the pedipalp chela manus mostly rounded and robust, and because most of the species are fossorial, living in burrows on the ground, the pelophilous ecomorphotype sensu [28].

Bioculus Stahnke, 1968 is endemic to Mexico and it comprises five species. It is distributed in Baja California Sur (four species), and one species can be found in Guerrero. Its disjunctive distribution pattern most likely reflects the separation of the Baja California Peninsula from mainland Mexico almost 5 mya [29,30]; however, a phylogenetic analysis and a molecular dating of the divergence of this genus are missing.

Diplocentrus Peters, 1861 is the most diverse genus of family Diplocentridae. It is distributed from southern US to Honduras [21] (Figure 2D). Mexico harbors almost 84\% percent of the species of the genus. Scorpions of this genus are present in almost all Mexican territories except in the Baja California Peninsula, where they are replaced by Bioculus. Species of Diplocentrus size ranges 
from the smallest Diplocentrus bereai Armas and Martín-Frías, 2004 (around $23 \mathrm{~mm}$ ) to the biggest Diplocentrus taibeli (Caporiacco, 1938) reaching almost $120 \mathrm{~mm}$.

Kolotl Santibáñez-López, Francke and Prendini, 2014 was recently created to accommodate two species with increasing neobothriotaxic pedipalps. It is distributed on the coast of Guerrero and in central Michoacán [31]. These scorpions are also big with a robust body (but not as big as Hadrurus species) living in crevices (the lithophilous ecomorphotype sensu [28]).

\subsection{Family Euscorpiidae Laurie, 1896}

Three of the four genera of this family are distributed in Mexico. Two of them (Megacormus Karsch, 1881 and Troglocormus Francke, 1981) are endemic to the Sierra Madre Oriental, from Tamaulipas to Oaxaca, whereas Plesiochactas Pocock, 1900 is also distributed in Chiapas and Guatemala. Scorpions of Megacormus and Plesiochactas are colored black or dark brown, while one species of Troglocormus is unpigmented and the other one is dark. Their size ranges $35-65 \mathrm{~mm}$. They have been neglected in the past because they are sometimes hard to find, and also because they do not reflect UV light as brightly as the other scorpion families.

Megacormus Karsch, 1880 is represented by four corticolous species [28] (Figure 2E) distributed from Tamaulipas to Oaxaca and Veracruz.

Plesiochactas Pocock, 1900 is represented by two species, one in Oaxaca and Veracruz and the other one is in Chiapas, but it is also present in Guatemala. Troglocormus Francke, 1981 is represented by two troglobitic species distributed in caves of San Luis Potosí and Tamaulipas, respectively.

\subsection{Family Superstitioniidae Stahnke, 1940}

This family is monotypic and endemic to southern Arizona and to the Baja California Peninsula. Superstitionia donensis Stanhke, 1940 is a small scorpion (approx. $25-30 \mathrm{~mm}$ long), with a shiny and lustrous yellow to orange-brown body coloration with irregular dusking black marks. This species is widely distributed in the Baja California Peninsula, and it inhabits different ecosystems: from deserts to semi deserts and rocky hills.

\subsection{Family Typhlochactidae Mitchell, 1971}

Scorpions of this family are strictly troglomorphic, and although only few species have been collected in epigean habitats (e.g., Typhlochactas sissomi Francke, Vignoli \& Prendini, 2009), most of the species are strictly troglobitic. This family is divided into two subfamilies: Alacraninae Vignoli and Prendini, 2009; and Typhlochactinae Mitchell, 1971. Subfamily Alacraninae comprises one genus Alacran Francke, 1982 and three species (see Supplementary Materials). These scorpions live in some of the deepest caves in the world (ca. $900 \mathrm{~m}$ below surface). They are well adapted to the environment. Some specimens of $A$. tartarus Francke, 1982 and A. triquimera Santibáñez-López, Francke and Prendini, 2014 have been collected or observed under water (Mr. William Steele, pers. observations).

Subfamily Typhlochactinae comprises three genera: the monotypic genera Sotanochactas Francke, 1986 and Stygochactas Vignoli and Prendini, 2009; and the polytypic genus Typhlochactas Mitchell, 1971 (with six species). Scorpions of this family are distributed and mostly restricted to caves of the Sierra Madre Oriental, from Tamaulipas to Oaxaca.

\subsection{Family Vaejovidae Thorell, 1876}

This family is the most diverse in Mexico. It is distributed from Canada to Guatemala [32]. Scorpions of this family are a major Nearctic component of the Mexican fauna. Most of the species inhabit desert, semi-desert or dunes and they are highly specialized. Mexico harbors currently 149 species in 21 genera (eight genera are endemic). Higher level systematics (i.e., subfamily level) and classification is currently in dispute. For the purposes of this contribution, we recognize three subfamilies: Syntropinae Kraepelin, 1905 (recently reviewed in [22,33]); Smeringurinae Soleglad and Fet, 2008 (although its monophyly has not been tested) and Vaejovinae Thorell, 1876. 
Subfamily Syntropinae comprises 11 genera and 56 species; however, several major generic revisions are underway and this diversity will increase. Genus Balsateres González-Santillán and Prendini, 2013 is monotypic and it is endemic to central Mexico (Michoacán and Mexico). Genus Chihuahuanus González-Santillán and Prendini, 2013 is represented by eight species, all of them distributed in northern Mexico and shared along the border with US. Genus Kochius Soleglad and Fet, 2008 is represented by nine species, mostly distributed in the Baja California Peninsula, except for Kochius sonorae (Williams, 1971), which is distributed in Sonora. Genus Konetontli González-Santillán and Prendini, 2013 (endemic to Mexico) is represented by 10 species distributed along the Pacific coast in the states of Guerrero, Michoacán, Jalisco, Nayarit and one species in Baja California Sur (which lives in pine oak forest; [34]). Genus Maaykuyak González-Santillán and Prendini, 2013 is represented by two species: one restricted to Baja California Sur [Maaykuyak vittatus (Williams, 1970)], and the other one [Maaykuyak waueri (Gertsch and Soleglad, 1972)] is distributed in northern Mexico (Durango, Chihuahua, Coahuila, and Nuevo Leon) and the US (Texas). Genus Mesomexovis González-Santillán and Prendini, 2013 (endemic to Mexico) is represented by seven species; they are distributed in Central and Southern Mexico. Genus Paravaejovis Williams, 1980 is represented by 11 species, all distributed in northern Mexico and Baja California Peninsula. Genus Syntropis Kraepelin, 1900 is represented by three species found in the Baja California Peninsula; these scorpions are among the largest in the vaejovids, and they are lithopilous (Prendini, 2001). Genus Thorellius Soleglad and Fet, 2008 is represented by three endemic species to Central Mexico (Colima, Jalisco, Michoacán, and México); they also are among the biggest vaejovids in Mexico. Genus Vizcaino González-Santillán and Prendini, 2013 is monotypic and endemic to the Vizcaino desert in the Baja California Peninsula; and the genus Kuarapu Francke and Ponce, 2011, also monotypic and endemic to the Balsas Depression in Michoacán.

Although the monophyly of subfamily Smeringurinae has not been tested in a phylogenetic context [22], the following genera are considered within the subfamily: Paruroctonus Werner, 1934 is represented in the country by 15 species (half its total diversity), which are distributed in northern Mexico (Sonora, Coahuila, Chihuahua) and Baja California; however, Paruroctonus gracilior (Hoffmann, 1931) is widely distributed in Texas, New Mexico and Arizona in US, and in Coahuila south to Aguascalientes and San Luis Potosí in Mexico. These scorpions are psammophilous [28]. Smeringurus Haradon, 1983 is represented by two species in Baja California, both psammophilous [28]; and Vejovoidus Stahnke, 1974, monotypic, endemic to the Vizcaino desert and strictly psammophilous.

Also, the monophyly of the subfamily Vaejovinae has not been tested; however, the following genera are currently considered within this subfamily: Franckeus Soleglad and Fet, 2005 (previously known as the "nitidulus" group within Vaejovis; Figure 2F) is represented by six species endemic to Mexico, distributed in Central Mexico, Northern Mexico and with one species in Baja California Sur. Scorpions of this genus are lithophilous [28]. Pseudouroctonus Stahnke, 1974 is represented by nine species distributed in northern Mexico and the Baja California Peninsula. Some species of this genus are troglobites and inhabit caves in Coahuila. Uroctonites Williams and Savary, 1991 with only one species in Sonora shared with Arizona, US. And finally, Vaejovis Koch, 1836, which is the most diverse genus of this family in Mexico with 40 species distributed from the north to the south (except in the Yucatán Peninsula) of Mexico. Most of the species are lapidicolous and corticolous; however, Vaejovis gracilis Gertsch and Soleglad, 1972 is a troglobite inhabiting caves in Veracruz.

There are three genera with insertae sedis status in the family Vaejovidae: Gertschius Graham and Soleglad, 2007, includes two species distributed in Sonora; Serradigitus Stahnke, 1974, which is represented by 14 species, most of them distributed in the Baja California Peninsula and the rest in northern Mexico (Sonora, Coahuila), and most of the species of this genus is lithophilous; and Stahnkeus Soleglad and Fet, 2006 represented by four species in Sonora and Baja California. 


\section{Geographical Hotspots and Environmental Variables as Indicators of Explored Areas in Mexico}

In order to know the extent of our knowledge on scorpion distribution in Mexico, the status of exploration in the country, and to serve as a base for study on the endemic hotspot distribution maps, we created a map plotting hotspots using a Mexican map divided into $25 \mathrm{~km}^{2}$ cells (quarter of degree grid cells) to show potential areas with more than two species (Figure 3). We calculated the number of species present in each cell. Species' occurrences were obtained from the records of the CNAN (Colección Nacional de Arácnidos, Instituto de Biología, UNAM), and from the literature. We decided not to include the cells where only one species was registered (i.e., type localities of the species with only one record, such as Typhlochactas sissomi), because it is known that there are several localities with at least one known scorpion species present in many areas of Mexico. Also, we eliminated dubious records (e.g., records with unknown georeference data or wrong locality name).

The hotspots map shows that (Figure 3) some areas appear to be better sampled (for example, Morelos, in central Mexico) while others are poorly sampled (e.g., Sonora, Chihuahua, Coahuila in northern Mexico). However, there is at least one species recorded in all Mexican states (not shown in the map). Hotspots mapped in Baja California Sur (Baja California Peninsula), the coast of Guerrero, the Isthmus of Tehuantepec, Central Valley in Oaxaca, the Valley of Cuicatlán-Tehuacan (Southern Mexico) and in the Yucatán Peninsula (Eastern Mexico) are consistent with published and unpublished records of several species. The hotspots in Baja California Sur, the Yucatan Peninsula and Central Valley in Oaxaca were previously recognized elsewhere $([5,13,14]$, respectively). Hotspots in the coast of Guerrero, the Isthmus of Tehuantepec and the Valley of Cuicatlán-Tehuacan were represented by five, six and seven species, respectively, not previously reported.

\section{Venomic Studies in Mexico}

Identification of scorpion venom components (mostly peptides and proteins), their functional characterization, and the cloning of the respective genes are some of the most studied aspects of Mexican scorpions. Over 150 scientific articles have been published since the earliest 1940s. A recent book dealing exclusively with "Scorpion Venom" was recently printed by the editorial Springer [35]. In this section, the most important components found in Mexican scorpions are revised. Scorpions use their venoms for capturing preys or defending themselves from predators. Millions of years of evolution permitted the selection and diversification of specific peptides or proteins with enzymatic activities that normally interfere with the cellular communication among cells of the individuals to which the scorpions inject venom. The peptides identified are exquisite ligands that either block or modify the function of ion-channels. Yet, their function is quite selective. There are peptides that recognize only ion channels from mammalians, crustaceans or insects [36]. These venom components are species specific. Two main peptidic components were found and described: (i) peptides that bind to sodium channels modifying the gating mechanisms [37]; (ii) peptides that recognize potassium channels and block their function [38,39].

Other components that recognize calcium channels were also described [40]. Specific enzymes that act as spreading factors like hyaluronidases are ubiquitous in all scorpion venoms studied thus far [41], but hydrolytic enzymes such as phopholipases or metalloproteinases are also present in these venoms [42-44]. None of these components were known, but deadly sting accidents occurred with humans in the country, which motivated the earlier studies conducted by physiologists at the Biomedical Institute of the National Autonomous University of México [45,46].

By the end of the 1970s, a French group under the leadership of Prof. Hervé Rochat published manuscripts describing the isolation and chemical characterization of toxic peptides from the Mexican scorpion Centruroides suffusus of Durango [47,48]. Toxin 2 from this scorpion was taken as a prototype of $\beta$-scorpion toxins affecting the opening mechanism of $\mathrm{Na}^{+}$-channels of excitable cells [49]. The same group of scientists described Toxin II from the North African scorpion Androctonus australis, taken as a prototype of the $\alpha$-scorpion toxins, which modify the closing mechanism of $\mathrm{Na}^{+}$-channels $[48,50-52]$. 
The analyses of the venom components of other scorpions of the species Centruroides elegans [53], Centruroides tecomanus [54] and mainly Centruroides noxius [55,56] were the first biochemical studies conducted in this country with Mexican scorpions. In 1982, Carbone and colleagues described the first scorpion toxin (Noxiustoxin), capable of blocking the function of $\mathrm{K}^{+}$-channels [57-59]. These findings constitute a landmark discovery that opened up a wide area of research on similar components present in other scorpions around the world, which were important for finally identifying and describing at the three-dimensional level the molecular structure of the first $\mathrm{K}^{+}$-channel molecule [60]. Among the Mexican scorpions, Centruroides noxius was found to contain the most potent venom against mammals. The LD50 of this venom is $5 \mu \mathrm{g}$ per $20 \mathrm{~g}$ mouse weight [55].

Apart from Noxiustoxin, another very important lethal component was found in this species of scorpion. It was named Cn2, a peptide with 66 amino acid residues very potent and specific ligand for $\mathrm{Na}^{+}$-channels of sub-type Nav1.6 [56,61-63]. This peptide was taken as a model peptide for preparation of a synthetic vaccine against scorpion venom intoxication [64,65]. It was also used for the development of monoclonal antibodies [61], which served as the basis for the isolation and preparation of single-chain antibodies of human origin, which are now being developed by the group of Dr. Balazar Becerril of the Biotechnology Institute in UNAM [66,67]. Actually, the three-dimensional structure of $\mathrm{Cn} 2$ and a protective single-chain antibody were obtained showing the interaction surfaces of toxin and antibody [68].

Other dangerous species of Mexican scorpions studied were Centruroides sculpturatus [69-71], Centruroides limpidus [72-74], Centruroides infamatus [74]. Advanced studies were conducted with venom components of these scorpions, all belonging to the family Buthidae, genus Centruroides [73-80]. The venom from these species is important due to the toxic effect caused by their stings [81].

Novel peptides, specific for $\mathrm{K}^{+}$-channels of the ether- $a$-go-go family (ERG-channels), were described and their function studied [82,83]. A series of review articles dealing with the biochemical and molecular biology of these Mexican scorpions is also available in the literature [37,38,83-90].

In addition to the specific peptides that are active on ion-channels of excitable and non-excitable cells, various peptides with different functions were reported, such as: antimicrobial peptides [91,92], anti-malaric peptides [93], anti-convulsive peptide [94], heterodimeric phospholipases [95], metalloprotease activity [44], and immunomodulatory peptides [96,97]. Many new components were isolated and characterized from the venom of scorpions not dangerous to humans $[42,43,91,98-100]$. Among the late described peptides are: Hadrucalcin, extracted from the venom of Hadrurus gertschi (= Hoffmannihadrurus gertschi), a peptide with affinity to ryanodine receptors and the potential to act as a delivery drug in the treatment of arrhythmogenic disease [40]; Hadrurin also from the venom of $H$. gertschi, a peptide with antimicrobial activity (inhibiting the growth of at least six bacteria) [91]; Phaiodotoxin, a peptide from the venom of the scorpion Anuroctonus phaiodactylus (= Anuroctonus pocoki, a misidentification), which is lethal to insects but not toxic to human, exhibiting great potential as a bio-insecticidal [43]; and Vm23 and Vm24, from the venom of Vaejovis mexicanus smithi (= Vaejovis smithi) as an immunosuppressive peptide which inhibits Kv1.3 channels of human lymphocytes, with important pharmacological characteristics suitable for drugs to treat autoimmune diseases [96,97].

Table 2 lists the number of different peptides identified in 16 different species of Mexican scorpions, the most relevant components found and the respective references. 
Table 2. Number of peptides and the most relevant components isolated from the venom of Mexican scorpions.

\begin{tabular}{cccc}
\hline Species & \# Peptides & Most Relevant & References \\
\hline Anuroctonus pococki & 8 & Phaiodotoxin & {$[43]$} \\
Centruroides elegans & 12 & CeII8 & {$[101]$} \\
Centruroides exilicauda & 17 & Neurotoxin Cex11 & {$[71]$} \\
Centruroides gracilis & 4 & Toxin Cg2 & {$[85]$} \\
Centruroides infamatus & 1 & Beta toxin Cii1 & {$[74]$} \\
Centruroides limpidus & 20 & Cll1, Cll2 & {$[74,79]$} \\
Centruroides margaritatus & 1 & Margatoxin & {$[102]$} \\
Centruroides noxius & 31 & Noxiustoxin, Cn2 & {$[56-59,61-63,103]$} \\
Centruroides sculpturatus & 26 & CsEv1 & {$[70]$} \\
Centruroides suffusus & 8 & CssII & {$[104]$} \\
Centruroides tecomanus & 37 & Clt1 & {$[77,105]$} \\
Hoffmannihadrurus gertschi & 13 & Hadrucalcin, Hadrurin, Hge scorpine & {$[40,91,98,106]$} \\
Mesomexovis punctatus & 15 & VpAmp1 & {$[107,108]$} \\
Mesomexovis subcristatus & 8 & ViSplp1 & {$[107]$} \\
Thorellius intrepidus & 14 & ViCaTx1 & {$[107]$} \\
Vaejovis mexicanus & 22 & Vejovine, Vm23, Vm24 & {$[92,96,97]$} \\
\hline
\end{tabular}

Figure 4 shows a graphical representation of the distribution of the various important pharmacological components identified in the venom of Mexican scorpions. The most abundant peptides described (over $73 \%$ ) are those that modify the gating mechanism of $\mathrm{Na}^{+}$-channels or block the function of $\mathrm{K}^{+}$-channels. This issue is due to the fact that these were the components first isolated from the venoms, because they were responsible for the human intoxication processes. More recently, other components were found such as the non-disulfide containing peptides (NDBP), among which are some with antimicrobial activity. Several enzymes were identified and their function described. Anti-parasitic peptides, like the scorpine-like ones, were isolated and their effect on malaria parasites was reported. Finally, peptides that recognize ryanodine sensitive calcium channels, called calcines, were also isolated and are under study now.

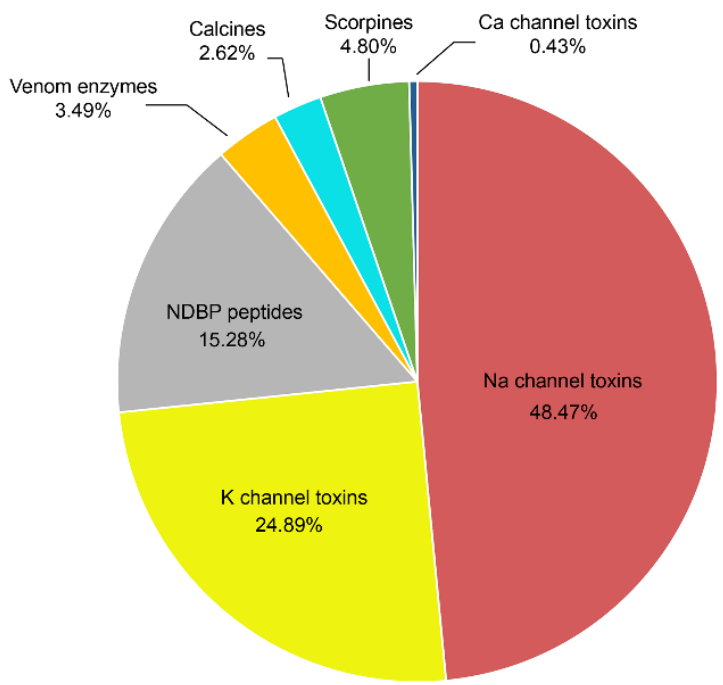

Figure 4. Proportion of the different peptides isolated from the venom of Mexican scorpions.

With the advent of the Next Generation Sequencing, the study of venom has changed. Transcriptomic analyses allow us to focus on subsets of target genes (i.e., those coding venom or toxic peptides). Such studies are now more common these days, including the venom gland transcriptomic analyses of Hoffmannihadrurus gertschi [106]; Centruroides tecomanus [105]; Mesomexovis punctatus, 
Mesomexovis subcristatus, Thorellius intrepidus and Vaejovis mexicanus [107]; and the global transcriptomic analysis of Centruroides noxius [103]. However, other studies are in progress and include the first venom gland transcriptomic analysis of one species of Megacormus, Superstitionia donensis and Hadrurus concolorous (Santibáñez-López, in prep.).

\section{Natural History, Behavior and Ecology Studies of Mexican Scorpions}

In sharp contrast with the numerous publications on Mexican scorpions' taxonomy, systematics and venomics, in the last decade there have been few contributions in these areas on scorpion biology.

In three chapters of the Biology of Scorpions ([6]; Chapters 4-6), many important aspects of life history, behavior and ecology were summarized. However, few species studied or mentioned were distributed in Mexico. Most of the studies were conducted in the Baja California Peninsula and for vaejovids, with the exception of few species in Centruroides, and Megacormus gertschi Díaz-Najera, 1966. For example, Francke [108] studied the courtship of Megacormus gertschi, finding that during mating, the male stings the female, revealing an unusual behavior previously unrecognized in other scorpions.

In the Scorpions 2001 book [109], few aspects on ecology and behavior were covered, but none for Mexican species.

It is not until 2003 when Ponce-Saavedra [110] studied the ecology and distribution of Centruroides balsasensis. After that, his laboratory has undertaken several ecological studies on genus Centruroides in Michoacán and Guerrero (for example [111]).

Later, Contreras-Garduño et al. [112] analyzed the function of the barbed mating plug in Mesomexovis punctatus (Karsch, 1879) from Hidalgo. The mating plug is part of the spermatophore produced by the male in order to inseminate the female. In the subfamily Syntropinae (family Vaejovidae), the mating plug has recurved spines that serve to anchor it inside the female's genital aperture; thus preventing further mating by that female and assuring the paternity of the male that provided the spermatophore. The plug dissolves gradually during the pregnancy and does not interfere with subsequent parturition.

Jiménez-Jiménez and Palacios-Gardell [113] studied the abundance and diversity of scorpions in six oases in Baja California Sur. The richest site contained 14 species and the poorest only three. Abundance at each locality varied with geomorphology, geographic conditions, and floristic composition, without a homogeneous pattern.

Lopez-Gonzalez et al. [114] found remains of the diplocentrid scorpion Diplocentrus peloncillensis Francke, 1975, in seven scats (= droppings) from black bears in the Sierra de San Luis, Sonora. Surprisingly, scorpions of various class sizes were present in the scats; and the frequency of scorpion remains in bear scats $(3.8 \%)$ indicates that scorpions do not constitute a large proportion of the diet of that black bear population. Nonetheless, this is the first report of bears feeding on scorpions anywhere in the world.

Quijano-Ravell et al. [115] determined the life cycle of the fossorial caraboctonid scorpion Hoffmannihadrurus gertschi (Soleglad, 1976) from field observations and monthly sampling during one year in deciduous scrub forest in central Guerrero. This species has seven stages (= instars) during its life history and requires at least four years to attain sexual maturity. Mating occurs at the end of the rainy season (July-October), and parturition occurs the following spring (April-May); thus, the gestation period lasts seven to eight months.

The same authors [116] analyzed the density, spatial distribution and biomass of H. gertschi at the same location as above. Densities varied from 0.35 scorpions per square meter down to $0.23 / \mathrm{m}^{2}$; an intermediate value among others reported for North American scorpions. Their spatial distribution is clumped (as opposed to uniform or scattered), evidenced by the young scorpions not travelling very far from the mother's burrow. Finally, the estimated biomass of $6.2 \mathrm{~kg}$ of scorpions per hectare is comparatively similar to studies made in Australia and California with other species of burrowing scorpions. 
In another contribution [117], the burrows of $H$. gertschi were examined. A total of 41 burrows of differently aged scorpions were excavated and measured: burrow entrance width, burrow total depth and burrow total length were positively correlated with the carapace length of the scorpion inhabiting each burrow. Each time a young scorpion prepares to molt, it seals its burrow from the inside; after it molts, it opens the entrance and enlarges its burrow, as evidenced by fresh tumuli of dirt at the burrow entrance containing remains of prey and of the exuvium shed during the molt.

Finally, Quijano-Ravell \& Ponce-Saavedra [118] analyzed litter size in Centruroides ornatus Pocock, 1902 , and found that the average number of young on the back of females differs significantly from the average number of embryos carried by pregnant females. That reduction in litter size could be due to a number of causes, both before, during, and after parturition.

Supplementary Materials: The following are available online at www.mdpi.com/2072-6651/8/1/2/s1.

Acknowledgments: We would like to thank Lorenzo Prendini for his constructive criticism to previous drafts of this contribution, and for suggestions on the presentation of the supplementary material. Carlos E. Santibáñez-López would like to thank Marisela Perzabal, Salvador González, Carlos González and Romel Borbon for their help getting some of the georeferences in the Baja California Peninsula. $m$ would also like to thank to the organizers of the summer 15' edition of Clubes de Ciencia Mexico, Rob Bryson and to all the enthusiastic students of the Scorpion Diversity in Mexico course, where most of the ideas here presented were conceived. This work was partially supported by a grant from Consejo Nacional de Ciencia y Tecnología, Mexican Government, under the number 237864 from the Sectorial Funds for Educational Research, and by a grant from DGAPA-UNAM under the number 200113, both granted to LDP.

Author Contributions: C.E.S.-L., L.D.P. and O.F.F. conceived the contents, C.E.S.-L., C.U. and O.F.F. analyzed the distributional data, C.E.S.-L. and C.U. produced the images. C.E.S.-L. and L.D.P. analyzed the venomics literature. C.E.S.-L., L.D.P., C.U. and O.F.F. wrote the paper.

Conflicts of Interest: The authors declare no conflict of interest.

\section{References}

1. Dunlop, J.A.; Selden, P.A. Scorpion fragments from the Silurian of Powys, Wales. Arachnology 2013, 16, $27-32$. [CrossRef]

2. Waddington, J.; Rudkin, D.M.; Dunlop, J.A. A new mid-Silurian aquatic scorpion-One step closer to land? Biol. Lett. 2015, 11. [CrossRef] [PubMed]

3. Santibáñez-López, C.E.; Francke, O.F.; Prendini, L. Shinning a light into the world's deepest caves: Phylogenetic systematics of the troglobiotic scorpion genus Alacran Francke, 1982 (Typhlochactidae: Alacraninae). Invertebr. Syst. 2014, 28, 643-664. [CrossRef]

4. Ochoa, J.A.; Ojanguren-Affilastro, A.A.; Mattoni, C.I.; Prendini, L. Systematic revision of the Andean scorpion genus Orobothriurus Maury, 1976 (Bothriuridae), with discussion of the altitude record for scorpions. Bull. Am. Mus. Nat. Hist. 2011, 359, 1-90. [CrossRef]

5. Williams, S.C. Scorpions of Baja California, Mexico, and Adjacent Islands. Occ. Pap. Calif. Acad. Sci. 1980, 135, 1-127.

6. Polis, G.A. The Biology of Scorpions; Stanford University Press: Palo Alto, CA, USA, 1990; p. 587.

7. Prendini, L. Scorpion diversity and distribution in southern Africa: Pattern and process. In African Biodiversity: Molecules, Organisms, Ecosystems, Proceedings of the 5th International Symposium on Tropical Biology, Bonn, Germany, 2-6 May 2004; Huber, B.A., Sinclair, B.J., Lampe, K.H., Eds.; Springer Verlag: New York, NY, USA, 2005; pp. 25-68.

8. Prendini, L. Order Scorpiones C.L. Koch, 1850. In Animal Biodiversity: An Outline of Higher-Level Classification and Survey of Taxonomic Richness; Zhang, Z.Q., Ed.; Zootaxa: Auckland, New Zealand, 2011; Volume 3148, pp. 115-177.

9. Rein-Ove, J. Scorpion Files. Tronheim. Norwegian University of Science and Technology, 2014. Available online: http:/ / www.ntnu.no/ub/scorpion-files (accessed on 1 October 2015).

10. Prendini, L.; Wheeler, W.C. Scorpion higher phylogeny and classification, taxonomic anarchy, and standards for peer review in online publishing. Cladistics 2005, 21, 446-494. [CrossRef] 
11. Sharma, P.P.; Fernández, R.; Esposito, L.; González-Santillán, E.; Monod, L. Phylogenomic resolution of scorpions reveals multilevel discordance with morphological phylogenetic signal. Proc. R. Soc. B. 2015, 282, 20142953. [CrossRef] [PubMed]

12. Francke, O.F. The genus Diplocentrus in the Yucatan Peninsula with description of two new troglobites (Scorpionida, Diplocentridae). Assoc. Mex. Cave Stud. Bull. 1979, 6, $49-61$.

13. Francke, O.F. Scorpions of the genus Diplocentrus from Oaxaca, Mexico. J. Arachnol. 1977, 4, 145-200.

14. Sissom, W.D. Systematics, biogeography and paleontology. In The Biology of Scorpions; Polis, G.A., Ed.; Stanford University Press: Palo Alto, CA, USA, 1990; pp. 64-160.

15. Fet, V.; Sissom, W.D.; Lowe, G.; Braunwalder, M.E. Catalog of the Scorpions of the World (1758-1998); The New York Entomological Society: New York, NY, USA, 2000; p. 690.

16. Lourenço, W.; Sissom, W.D. Scorpiones. In Biodiversidad, Taxonomía y Biogeografía de Artrópodos de México: Hacia una Sintesis de su Conocimiento; Llorente-Bousquets, J.E., Soriano, E.G., Papavero, N., Eds.; Universidad Nacional Autónoma de México/CONABIO/BAYER: Mexico City, Mexico, 2000; Volume 2, pp. 115-135.

17. Armas, L.F.; Martín-Frías, E.; Estévez-Ramírez, J. Lista anotada de las especies mexicanas del género Centruroides Marx, 1890 (Scorpiones: Buthidae). Rev. Iber. Aracnol. 2003, 8, 93-98. (In Spanish)

18. Francke, O.F. Biodiversidad de Arthropoda (Chelicerata: Arachnida ex. Acari) en México. Rev. Mex. Biodivers. 2013, 85, S408-S418. (In Spanish) [CrossRef]

19. Sissom, W.D.; Hendrixson, B. Scorpion biodiversity and patterns of endemism in northern Mexico. In Biodiversity, Ecosystems and Conservation in Northern Mexico; Cartron, J.L.E., Ceballos, G., Felger, R.S., Eds.; Oxford University Press: Oxford, UK, 2005; pp. 122-137.

20. Soleglad, M.E.; Fet, V. Contributions to scorpion systematics. III. Subfamilies Smeringurinae and Syntropinae (Scorpiones: Vaejovidae). Euscorpius 2008, 71, 1-115.

21. Santibáñez-López, C.E.; Francke, O.F.; Prendini, L. Phylogeny of the North American scorpion genus Diplocentrus Peters, 1861 (Scorpiones: Diplocentridae) based on morphology, nuclear and mitochondrial DNA. Arthropod Syst. Phylo. 2014, 72, 257-279.

22. González-Santillán, E.; Prendini, L. Phylogeny of the North American vaejovid scorpion subfamily Syntropinae Kraepelin, 1905, based on morphology, mitochondrial and nuclear DNA. Cladistics 2015, 31, 341-405. [CrossRef]

23. Riquelme, F.; Villegas-Guzmán, G.; González-Santillán, E.; Córdova-Tabares, V.; Francke, O.F.; Piedra-Jiménez, D.; Estrada-Ruiz, E.; Luna-Castro, B. New fossil scorpion from the Chiapas Amber Lagerstätte. PLoS ONE 2015, 10. [CrossRef] [PubMed]

24. Ponce-Saavedra, J.; Francke, O.F.; Cano-Camacho, H.; Hernández-Calderón, E. Evidencias morfológicas y moleculares que validan como especie a Centruroides tecomanus (Scorpiones, Buthidae). Rev. Mex. Biodivers. 2009, 80, 71-84. (In Spanish)

25. Santibáñez-López, C.E.; Contreras-Félix, G.A. Two new species of Centruroides Marx 1890 (Scorpiones: Buthidae) from Oaxaca, Mexico. Zootaxa 2013, 3734, 130-140. [CrossRef] [PubMed]

26. Teruel, R.; Kovarik, F.; Baldazo-Monsivais, J.G.; Hoferek, D. A new species of Centruroides of the "nigrovariatus" group (Scorpiones: Buthidae) from southern Mexico. Rev. Iber. Aracnol. 2015, 26, 3-14.

27. Francke, O.F.; Teruel, R.; Santibáñez-López, C.E. A new genus and a new species of scorpion (Scorpiones: Buthidae) from southeastern Mexico. J. Arachnol. 2014, 42, 220-232. [CrossRef]

28. Prendini, L. Substratum specialization and speciation in southern African scorpions: The Effect Hypothesis revisited. In Scorpions 2001. In Memoriam Gary A. Polis; Fet, V., Selden, P.A., Eds.; British Arachnological Society: London, UK, 2001; pp. 113-118.

29. Gastil, B.; Minch, J.; Philips, R.P. The geology and ages of islands. In Island Biogeography in the Sea of Cortez; Case, T.J., Cody, M.L., Eds.; University of California Press: San Diego, CA, USA, 1983; pp. 13-25.

30. Grismer, L.L. The origin and evolution of the peninsular herpetofauna of Baja California, Mexico. Herpetol. Nat. Hist. 1994, 2, 51-106.

31. Santibáñez-López, C.E.; Francke, O.F.; Prendini, L. Kolotl, n. gen. (Scorpiones: Diplocentridae), a new scorpion genus from Mexico. Am. Mus. Novit. 2014, 3815, 1-28. [CrossRef]

32. Sissom, W.D. Family Vaejovidae Thorell, 1876. In Catalog of the Scorpions of the World (1758-1998); Fet, V., Sissom, W.D., Lowe, G., Braunwalder, M.E., Eds.; New York Entomological Society: New York, NY, USA, 2000; pp. 503-553. 
33. González-Santillán, E.; Prendini, L. Redefinition and generic revision of the North American vaejovid scorpion subfamily Syntropinae Kraepelin, 1905, with descriptions of six new genera. Bull. Am. Mus. Nat. Hist. 2013, 382, 1-71. [CrossRef]

34. González-Santillán, E.; Prendini, L. Systematic revision of the North American syntropine vaejovid scorpions with a subaculear tubercle, Konetontli González-Santillán and Prendini, 2013. Bull. Am. Mus. Nat. Hist. 2015, 397, 1-78. [CrossRef]

35. Gopalakrishnakone, P.; Possani, L.D.; Schwartz, E.; Rodríguez de la Vega, R. Scorpion Venom; Springer: Berlin, Germany, 2015; p. 575.

36. Possani, L.D. Structure of scorpion toxins. In Handbook of Natural Toxins; Tu, A.T., Ed.; Marcel Dekker Inc: New York, NY, USA, 1984; Volume 2, pp. 513-550.

37. De la Vega, R.; Possani, L.D. Minireview: Current views on scorpion toxins specific for $\mathrm{K}^{+}$-channels. Toxicon 2004, 43, 865-875. [CrossRef] [PubMed]

38. De la Vega, R.; Possani, L.D. Overview of scorpion toxins specific for $\mathrm{Na}^{+}$channels and related peptides: Biodiversity, structure-function relationships and evolution. Toxicon 2005, 46, 831-844. [CrossRef] [PubMed]

39. Tytgat, J.; Chandy, K.G.; Garcia, L.M.; Gutman, G.A.; Martin-Eauclaire, M.F.; van de Walt, J.J.; Possani, L.D. A unified nomenclature for short chain peptides isolated from scorpion venoms: Alpha-KTx molecular subfamilies. Trends Pharmacol. Sci. 1999, 20, 445-447. [CrossRef]

40. Schwartz, E.F.; Capes, E.M.; Diego-García, E.; Zamudio, F.Z.; Fuentes, O.; Possani, L.D.; Valdivia, H.H. Purification, amino acid sequence and functional properties of hadrucalcin, a peptide from Hadrurus gertschi scorpion venom with pharmacological activity on rynodine receptors. Br. J. Pharmacol. 2009, 157, 392-403. [CrossRef] [PubMed]

41. Alagón, A.C.; Possani, L.D. Utilización de cromatografía por afinidad para la purificación de enzimas de venenos animales. In Proceedings of the First InterAmerican Symposium on Enzyme Biotechnology, Mexico City, Mexico, 1984; pp. 125-132. (In Spanish)

42. Valdez-Cruz, N.A.; Batista, C.V.F.; Possani, L.D. Phaiodactylipin, a glycosylated heterodimericdo phospholipase A2, from the scorpion Anuroctonus phaiodactylus. Eur. J. Biochem. 2004, 271, 1453-1464. [CrossRef] [PubMed]

43. Valdez-Cruz, N.A.; Batista, C.V.F.; Zamudio, F.Z.; Bosmans, F.; Tytgat, J.; Possani, L.D. Phaiodotoxin, a novel structural class of insect-toxin isolated from the venom of the Mexican scorpion Anuroctonus phaiodactylus. Eur. J. Biochem. 2004, 271, 4753-4761. [CrossRef] [PubMed]

44. Ortiz, E.; Rendón-Anaya, M.; Rego, S.C.; Schwartz, E.F.; Possani, L.D. Antarease-like Zn-metalloproteases are ubiquitous in the venom of different scorpion genera. Biochim. Biophys. Acta 2014, 1840, 1738-1746. [CrossRef] [PubMed]

45. Del Pozo, E.C.; Anguiano, L.G.; González, J. Acciones del veneno de alacrán sobre el sistema vaso-motor. Rev. Inst. Salubr. Enferm. Trop. 1944, 5, 227-240. (In Spanish)

46. Del Pozo, E.C.; González, J.; Méndez, T.H. Acciones del veneno de alacrán sobre el aparato respiratorio. Rev. Inst. Salubr. Enferm. Trop. 1945, 6, 77-84. (In Spanish)

47. García, G.P. Étude des Neurotoxines du Venin du Scorpion Mexicain "Centruroides Suffusus Suffusus". Ph.D. Thesis, Université de Nice, Nice, France, 1979. (In French)

48. Rochat, H.; Bernard, P.; Couraud, F. Scorpion toxins: Chemistry and mode of action. In Advances in Cytopharmacology; Ceccarelli, B., Clementi, F., Eds.; Raven Press: New York, NY, USA, 1979; Volume 3, pp. 325-334.

49. Jover, E.; Couraud, F.; Rochat, H. Two types of scorpion neurotoxins characterized by their binding to two separate receptor sites on rat brain synaptosomes. Biochem. Biophys. Res. Commun. 1980, 95, 1607-1613. [CrossRef]

50. Rochat, H.; Rochat, C.; Sampieri, F.; Miranda, F.; Lissitzky, S. The amino acid sequence of neurotoxin II of Androctonus australis Hector. Eur. J. Biochem. 1972, 28, 381-388. [CrossRef] [PubMed]

51. Wheeler, K.P.; Watt, D.D.; Lazdunski, M. Classification of Na channel receptors specific for scorpion toxins. Pflüg. Arch. (Eur. J. Phsysiol.) 1983, 387, 164-165. [CrossRef]

52. Possani, L.D.; Becerril, B.; Delepierre, M.; Tytgat, J. Scorpion toxins specific for $\mathrm{Na}^{+}$-channels. Eur. J. Biochem. 1999, 264, 287-300. [CrossRef] [PubMed]

53. Possani, L.D.; Ramirez, G.A.; Fletcher, P.L., Jr.; Gurrola, M.A.H. Isolation of two mammalian toxins from the venom of the Mexican scorpion Centruroides elegans (Thorell). FEBS Lett. 1978, 91, 261-264. [CrossRef] 
54. Possani, L.D.; Fletcher, P.L., Jr.; Alagon, A.C.; Julia, J.Z. Purification and characterization of a mammalian toxin from venom of the Mexican scorpion Centruroides limpidus tecomanus Hoffmann. Toxicon 1980, 18, 175-183. [CrossRef]

55. Dent, M.A.R.; Possani, L.D.; Ramírez, G.A.; Fletcher, P.L., Jr. Purification and characterization of two mammalian toxins from the venom of the Mexican scorpion Centruroides noxius Hoffmann. Toxicon 1980, 18, 343-350. [CrossRef]

56. Possani, L.D.; Dent, M.A.R.; Martin, B.M.; Maelicke, A.; Svendsen, I. The amino terminal sequence of several toxins from the venom of the Mexican scorpion Centruroides noxius Hoffmann. Carlsberg Res. Commun. 1981, 46, 207-214. [CrossRef]

57. Carbone, E.; Wanke, E.; Prestipino, G.; Possani, L.D.; Maelicke, A. Selective blockage of voltage-dependent $\mathrm{K}^{+}$channels by a novel scorpion toxin. Nature 1982, 296, 90-91. [CrossRef] [PubMed]

58. Carbone, E.; Prestipino, G.; Wanke, E.; Possani, L.D.; Maelicke, A. Selective action of scorpion neurotoxins on the ionic currents of the squid giant axon. Toxicon 1983, 3, 57-60. [CrossRef]

59. Possani, L.D.; Martin, B.; Svendsen, I. The primary structure of Noxiustoxin: $\mathrm{A} \mathrm{K}^{+}$channel blocking peptide from the venom of the scorpion Centruroides noxius Hoffmann. Carlsberg Res. Commun. 1982, 47, 285-289. [CrossRef]

60. Doyle, D.A.; Morais-Cabral, J.; Pfuetzner, R.A.; Kuo, A.; Gulbis, J.M.; Cohen, S.L.; Chait, B.R.; MacKinnon, R. The structure of potassium channel: Molecular basis of $\mathrm{K}^{+}$conduction and selectivity. Science 1998, 280, 69-77. [CrossRef] [PubMed]

61. Zamudio, F.; Saavedra, R.; Martin, B.M.; Gurrola-Briones, G.; Herion, P.; Possani, L.D. Amino acid sequence an immunological characterization with monoclonal antibodies of two toxins from the venom of the scorpion Centruroides noxius Hoffmann. Eur. J. Biochem. 1992, 204, 281-292. [CrossRef] [PubMed]

62. Pintar, A.; Possani, L.D.; Delepierre, M. Solution structure of toxin 2 from Centruroides noxius Hoffmann, a beta scorpion neurotoxin acting on sodium channels. J. Mol. Biol. 1999, 287, 359-367. [CrossRef] [PubMed]

63. Schiavon, E.; Sacco, T.; Restano-Cassulini, R.; Gurrola, G.B.; Tempia, F.; Possani, L.D.; Wanke, E. Resurgent current and voltage sensor-trapping enhanced activation of a $\beta$-scorpion toxin solely in Nav1.6 sodium channel: Significance in mice Purkinje neurons. J. Biol. Chem. 2006, 281, 20326-20337. [CrossRef] [PubMed]

64. Calderón-Aranda, E.S.; Olamendi-Portugal, T.; Possani, L.D. The use of synthetic peptides can be a misleading approach to generate vaccines against scorpion toxins. Vaccine 1995, 13, 1198-1206. [CrossRef]

65. Calderón-Aranda, E.S.; Selisko, B.; York, E.J.; Gurrola, G.B.; Stewart, J.M.; Possani, L.D. Mapping of an epitope recognized by a neutralizing monoclonal antiboby specific to toxin $\mathrm{Cn} 2$ from the scorpion Centruroides noxius, using discontinuous synthetic peptides. Eur. J. Biochem. 1999, 264, 746-755. [CrossRef] [PubMed]

66. Riaño-Umbarila, L.; Juárez-González, R.V.; Olamendi-Portugal, T.; Ortiz-León, M.; Possani, L.D.; Becerril, B. A strategy for the generation of specific human antibodies by directed evolution and phage display. An example of a single-chain antibody fragment that neutralizes a major component of scorpion venom. FEBS J. 2005, 272, 2591-2601. [CrossRef] [PubMed]

67. Riaño-Umbarila, L.; Contreras-Ferrat, G.; Olamendi-Portugal, T.; Morelos-Juárez, C.; Corzo, G.; Possani, L.D.; Becerril, B. Exploiting cross-reactivity to neutralize two different scorpion venoms with one single chain antibody fragment. J. Biol. Chem. 2011, 286, 6143-6151. [CrossRef] [PubMed]

68. Canul-Tec, J.C.; Riaño-Umbarila, L.; Rudinño-Pinera, E.; Becerril, B.; Possani, L.D.; Torres-Larios, A. Structural basis of neutralization of the major toxic component from the scorpion Centruroides noxius Hoffmann by a human-derived single chain antibody fragment. J. Biol. Chem. 2011, 286, 20892-20900. [CrossRef] [PubMed]

69. Babin, D.R.; Watt, D.D.; Goos, S.M.; Mlenjek, R.V. Amino acid sequence of neurotoxic protein variants from the venom of Centruroides sculpturatus Ewing. Arch. Biochem. Biophys. 1974, 164, 694-706. [CrossRef]

70. Corona, M.; Valdez-Cruz, N.A.; Merino, E.; Zurita, M.; Possani, L.D. Genes and peptides from the scorpion Centruroides sculpturatus Ewing, that recognize $\mathrm{Na}^{+}$-channels. Toxicon 2001, 39, 1893-1898. [CrossRef]

71. Valdez-Cruz, N.A.; Dávila, S.; Licea, A.; Corona, M.; Zamudio, F.Z.; Garcia-Valdes, J.; Boyer, L.; Possani, L.D. Biochemical, genetic and physiological characterization of venoms components from two species of scorpions: Centruroides exilicauda Wood and Centruroides sulpturatus Ewing. Biochimie 2004, 86, 387-396. [CrossRef] [PubMed]

72. Alagon, A.C.; Guzmán, H.S.; Martin, B.M.; Ramírez, A.N.; Carbone, E.; Possani, L.D. Isolation and characterization of two toxins from the Mexican scorpion Centruroides limpidus limpidus Karsch. Comp. Biochem. Physiol. 1988, 89, 153-162. [CrossRef] 
73. Ramírez, A.N.; Martín, B.M.; Gurrola, G.B.; Possani, L.D. Isolation and characterization of a novel toxin from the venom of the scorpion Centruroides limpidus limpidus Karsch. Toxicon 1994, 32, 479-490. [CrossRef]

74. Dehesa-Davila, M.; Ramírez, A.N.; Zamudio, F.Z.; Gurrola, G.; Lievano, A.; Darszon, A.; Possani, L.D. Structural and functional comparison of toxins from the venom of the scorpions Centruroides infamatus infamatus, Centruroides limpidus limpidus and Centruroides noxius. Comp. Biochem. Physiol. 1996, 113B, 331-339. [CrossRef]

75. Possani, L.D.; Martín, B.M.; Svendsen, I.; Rode, G.S.; Erickson, B.W. Scorpion Toxins from Centruroides noxius and Tityus serrulatus: Primary Structures and Sequence Comparison by metric analysis. Biochem. J. 1985, 229, 739-750. [CrossRef] [PubMed]

76. Yatani, A.; Kirsh, G.E.; Possani, L.D.; Brown, A.M. Effects of two new world scorpion toxins on single channel and whole cell cardiac sodium channels. Am. J. Physiol. 1988, 254, H443-H451. [PubMed]

77. Ramírez, A.N.; Gurrola, G.B.; Martín, M.B.; Possani, L.D. Isolation of several toxins from the venom of the scorpion Centruroides limpidus tecomanus Hoffmann. Toxicon 1988, 26, 773-783. [CrossRef]

78. Gurrola, G.B.; Moreno-Hagelsieb, G.; Zamudio, F.Z.; García, M.; Soberon, X.; Possani, L.D. The disulfide bridge of toxin 2 from the scorpion Centruroides noxius. FEBS Lett. 1994, 347, 59-62. [CrossRef]

79. Lebreton, F.; Delepierre, M.; Ramírez, A.N.; Balderas, C.; Possani, L.D. Primary and NMR three-dimensional structure determination of a novel crustacean toxin from the venom of the scorpion Centruroides limpidus limpidus Karsch. Biochemistry 1994, 33, 11135-11149. [CrossRef] [PubMed]

80. Martín, B.M.; Ramírez, A.N.; Gurrola, G.B.; Nobile, M.; Prestipino, G.; Possani, L.D. Novel K ${ }^{+}$-channel blocking toxins from the venom of the scorpion Centruroides limpidus limpidus Karsch. Biochem. J. 1994, 304, 51-56. [CrossRef] [PubMed]

81. Espino-Solís, G.; Riaño-Umbarila, L.; Becerril, B.; Possani, L.D. Antidotes against venomous animals: State of the art and prospectives. J. Proteom. 2009, 72, 183-199. [CrossRef] [PubMed]

82. Pardo-López, L.; Zhang, M.; Liu, J.; Jiang, M.; Possani, L.D.; Tseng, G.N. Mapping the binding site of a HERG-specific peptide toxin (ErgTx) to the channel's outer vestibule. J. Biol. Chem. 2002, 277, 16403-16411. [CrossRef] [PubMed]

83. Corona, M.; Gurrola, G.B.; Merino, E.; Restano-Cassulini, R.; Valdez-Cruz, N.A.; García, B.; Ramírez-Domínguez, M.E.; Coronas, F.I.V.; Zamudio, F.Z.; Wanke, E.; et al. A large number of novel Ergtoxin-like genes and ERG $\mathrm{K}^{+}$-channels blocking peptides from scorpions of the genus Centruroides. FEBS Lett. 2002, 532, 121-126. [CrossRef]

84. Becerril, B.; Corona, M.; García, C.; Bolívar, F.; Possani, L.D. Cloning of genes encoding scorpion toxins: An interpretive review. J. Toxicol. 1995, 14, 339-357. [CrossRef]

85. Possani, L.D.; Merino, E.; Corona, M.; Bolívar, F.; Becerril, B. Peptides and genes coding for scorpion toxins that affect ion-channels. Biochimie 2000, 82, 861-868. [CrossRef]

86. Huys, I.; Olamendi-Portugal, T.; García-Gómez, B.I.; Vandenberghe, I.; van Beeumen, J.; Dyason, K.; Clynen, E.; Zhu, S.; van der Walt, J.; Possani, L.D.; et al. A subfamily of acidic $\alpha-\mathrm{K}^{+}$toxins. J. Biol. Chem. 2004, 279, 2781-2789. [CrossRef] [PubMed]

87. De la Vega, R.; Schwartz, E.F.; Possani, L.D. Mining on scorpion venom biodiversity. Toxicon 2010, 56, 1155-1161. [CrossRef] [PubMed]

88. Quintero-Hernández, V.; Ortiz, E.; Rendón-Anaya, M.R.; Schwartz, E.F.; Becerril, B.; Corzo, G.; Possani, L.D. Scorpion and spider venom peptides: Gene cloning and peptide expression. Toxicon 2011, 58, $644-663$. [CrossRef] [PubMed]

89. Quintero-Hernández, V.; Jiménez-Vargas, J.M.; Gurrola, G.B.; Valdivia, H.H.; Possani, L.D. Scorpion venom components that affect ion-channels function. Toxicon 2013, 76, 328-342. [CrossRef] [PubMed]

90. Pedraza-Escalona, M.; Possani, L.D. Scorpion $\beta$-toxins and voltage-gated sodium channels: Interactions and toxicity effects. Front. Biosci. Landmark 2013, 18, 572-587. [CrossRef]

91. Torres-Larios, A.; Gurrola, G.B.; Zamudio, F.Z.; Possani, L.D. Hadrurin, a new antimicrobial peptide from the venom of the scorpion Hadrurus aztecus. Eur. J. Biochem. 2000, 267, 5023-5031. [CrossRef] [PubMed]

92. Hernández-Aponte, C.A.; Silva-Sánchez, J.; Quintero-Hernández, V.; Rodríguez-Romero, A.; Balderas, C.; Possani, L.D.; Gurrola, G.B. Vejovine, a new antibiotic from the scorpion venom of Vaejovis mexicanus. Toxicon 2011, 57, 84-92. [CrossRef] [PubMed] 
93. Diego-García, E.; Schwartz, E.F.; D’Suze, G.; Roman-González, S.A.; Batista, C.V.; García, B.I.; de la Vega, R.; Possani, L.D. Wide phylogenetic distribution of Scorpine and long-chain beta-KTx-like peptides in scorpion venoms: Identification of "orphan" components. Peptides 2007, 28, 31-37. [CrossRef] [PubMed]

94. Corona, M.; Coronas, F.V.I.; Merino, E.; Becerril, B.; Gutiérrez, R.; Rebolledo-Antúnez, S.; García, D.E.; Possani, L.D. A novel class of peptide found in scorpion venom with neurodepressant effects in peripheral and central nervous system of the rat. Biochim. Biophys. Acta 2003, 1649, 58-67. [PubMed]

95. Valdez-Cruz, N.A.; Segovia, L.; Corona, M.; Possani, L.D. Sequence analysis and phylogenetic relationships of genes encoding heterodimeric phospholipases A2 from the venom of the scorpion Anuroctonus phaiodactylus. Gene 2007, 396, 149-158. [CrossRef] [PubMed]

96. Gurrola, G.B.; Hernández-López, R.; de la Vega, R.; Varga, Z.; Batista, C.F.; Salas-Castillo, S.; Panyi, G.; Del Rio Portilla, F.; Possani, L.D. Structure, function and chemical synthesis of Vaejovis mexicanus peptide 24: A novel potent blocker of Kv1.3 potassium channels of human T lymphocytes. Biochemistry 2012, 51, 4049-4061. [CrossRef] [PubMed]

97. Varga, Z.; Gurrola, G.B.; Papp, F.; de la Vega, R.; Pedraza-Alva, G.; Tajhya, R.B.; Gaspar, R.; Cárdenas, L.; Rosenstein, Y.; Beeton, C.; et al. Vm24, a natural immunosuppressant peptide potently and selectively blocks Kv1.3 potassium channels of human T cells. Mol. Pharmacol. 2012, 82, 372-382. [CrossRef] [PubMed]

98. Schwartz, E.F.; Schwartz, C.A.; Gómez-Lagunas, F.; Zamudio, F.Z.; Possani, L.D. HgeTx1, the first $\mathrm{K}^{+}$-channel specific toxin characterized from the venom of the scorpion Hadrurus gertschi Soleglad. Toxicon 2006, 48, 1046-1053. [CrossRef] [PubMed]

99. Ramírez-Carreto, S.; Quintero-Hernández, V.; Jiménez-Vargas, J.M.; Corzo, G.; Possani, L.D.; Becerril, B.; Ortiz, E. Gene cloning and functional characterization of four novel antimicrobial-like peptides from scorpions of the family Vaejovidae. Peptides 2012, 34, 290-295. [CrossRef] [PubMed]

100. Ramírez-Carreto, S.; Jiménez-Vargas, J.M.; Rivas-Santiago, B.; Corzo, G.; Possani, L.D.; Becerril, B.; Ortiz, E. Peptides from the scorpion Vaejovis punctatus with broad antimicrobial activity. Peptides 2015, 73, 51-59. [CrossRef] [PubMed]

101. Vandendriessche, T.; Olamendi-Portugal, T.; Zamudio, Z.F.; Possani, L.D.; Tytgat, J. Isolation and characterization of two novel scorpion toxins: The alpha-toxin-like Cell8, specific for Nav1.7 channels and the classical anti-mammalian Cell9, specific for Nav1.4 channels. Toxicon 2010, 56, 613-623. [CrossRef] [PubMed]

102. García-Calvo, M.; Leonard, R.J.; Novick, J.; Stevens, S.P.; Schmalhofer, W.; Kaczorowski, G.J.; García, M.L. Purification, characterization and biosynthesis of margatoxin, a component of Centruroides margaritatus venom that selectively inhibits voltage-dependent potassium channels. J. Biol. Chem. 1993, 268, 18866-18874. [PubMed]

103. Rendon-Anaya, M.; Delaye, L.; Possani, L.D.; Herrera-Estrella, A. Global transcriptome analysis of the scorpion Centruroides noxius: New toxin families and evolutionary insights from an ancestral scorpion species. PLOS ONE 2012, 8. [CrossRef] [PubMed]

104. Estrada, G.; García, B.I.; Schiavon, E.; Ortiz, E.; Cestele, S.; Wanke, E.; Possani, L.D.; Corzo, G. Four disulfide-bridged scorpion beta neurotoxin CssI: Heterologous expression and proper folding in vitro. Biochim. Biophys. Acta 2007, 1170, 1161-1168. [CrossRef] [PubMed]

105. Valdez-Velázquez, L.L.; Quintero-Hernández, V.; Romero-Gutiérrez, M.T.; Coronas, F.I.V.; Possani, L.D. Mass fingerprinting of the venom and transcriptome of venom gland of scorpion Centruroides tecomanus. PLoS ONE 2013, 8. [CrossRef]

106. Schwartz, E.F.; Diego-García, E.; de la Vega, R.; Possani, L.D. Transcriptome analysis of the venom gland of the Mexican scorpion Hadrurus gertschi (Arachnida: Scorpiones). BMC Genom. 2007, 8, 119. [CrossRef] [PubMed]

107. Quintero-Hernández, V.; Ramírez-Carreto, S.; Romero-Guitiérrez, M.T.; Valdez-Velázquez, L.; Becerril, B.; Possani, L.D.; Ortiz, E. Transcriptome analysis of scorpion species belonging to the Vaejovis genus. PLoS ONE 2015, 10. [CrossRef]

108. Francke, O.F. Observations on the reproductive biology and life history of Megacormus gertschi Díaz (Scorpiones, Chactidae, Megacorminae). J. Arachnol. 1979, 7, 223-230.

109. Fet, V.; Selden, P.A. Scorpions 2001: In memoriam Gary A. Polis; British Arachnological Society: London, UK, 2001; p. 416. 
110. Ponce-Saavedra, J. Ecología y Distribución del Género Centruroides Marx 1890 (Scorpiones: Buthidae) en la Depresión del Balsas, Michoacán, México. Ph.D. Thesis, Universidad Autónoma de Querétaro, Querétaro, Mexico, 2003. (In Spanish)

111. Ponce-Saavedra, J.; Francke, O.F.; Suzán, H. Actividad superficial y utilización del hábitat por Centruroides balsasensis Ponce y Francke (Scorpiones: Buthidae). Biológicas 2006, 8, 130-137. (In Spanish)

112. Contreras-Garduño, J.; Peretti, A.V.; Córdoba-Aguilar, A. Evidence that mating plug is related to null female mating activity in the scorpion Vaejovis punctatus. Ethology 2006, 112, 152-163. [CrossRef]

113. Jiménez-Jiménez, M.L.; Palacios-Cardiel, C. Scorpions of desert oases in the southern Baja California Peninsula. J. Arid Environ. 2009, 74, 70-74. [CrossRef]

114. López-González, C.A.; Jones, R.W.; Silva-Hurtado, C.; Sáyago-Vázquez, I. Scorpions are a food item of American Black Bears in Sonora, Mexico. West. N. Am. Nat. 2009, 69, 131-133. [CrossRef]

115. Quijano-Ravell, A.F.; Ponce-Saavedra, J.; Francke, O.F. Ciclo de vida de Hadrurus gertschi Soleglad (Scorpiones, Iuridae) en una localidad del Estado de Guerrero, Mexico. Rev. Iber. Aracnol. 2011, 19, 133-145. (In Spanish)

116. Quijano-Ravell, A.F.; Ponce-Saavedra, J.; Francke, O.F. Densidad, distribución espacial y biomasa de Hadrurus gertschi Soleglad (Scorpiones, Iuridae) en una localidad de Guerrero, Mexico. Rev. Iber. Aracnol. 2012, 20, 35-43. (In Spanish)

117. Quijano-Ravell, A.F.; Francke, O.F.; Ponce-Saavedra, J.; Villaseñor-Ramos, M.A. Caracterización de las madrigueras de Hadrurus gertschi Solegald (Scorpiones: Iuridae) en una localidad de Guerrero, México. Rev. Iber. Aracnol. 2012, 20, 45-55. (In Spanish)

118. Quijano-Ravell, A.F.; Ponce-Saavedra, J. Comparación de los tamaños de camada usando crías y embriones en Centruroides ornatus Pocock, 1902 (Scorpiones: Buthidae) en Michoacán, México. Entomol. Mex. 2015, 2, 59-65. (In Spanish)

(C) 2015 by the authors; licensee MDPI, Basel, Switzerland. This article is an open access article distributed under the terms and conditions of the Creative Commons by Attribution (CC-BY) license (http://creativecommons.org/licenses/by/4.0/). 